九州大学学術情報リポジトリ

Kyushu University Institutional Repository

A New Approach to Pectin Manufacture by Copper Method : Part 3. Demineralization of Dry Cu-AlPectin Complex and Characteristics of the Pectins Produced Thereby

Kausar, Pervez

Food Processing Laboratory, Faculty of Agriculture, Kyushu University

Nomura, Danj i

Food Processing Laboratory, Faculty of Agriculture, Kyushu University

https://doi.org/10.5109/23743

出版情報：九州大学大学院農学研究院紀要. 26 (2/3)，pp.111-119，1982-02. Kyushu University バージョン：

権利関係 : 


\title{
A New Approach to Pectin Manufacture by Copper Method \\ Part 3. Demineralization of Dry Cu-Al-Pectin Complex and Characteristics of the Pectins Produced Thereby
}

\section{Pervez Kausar and Danji Nomura}

\author{
Food Processing Laboratory, Faculty of Agriculture, \\ Kyushu University 46-09, Fukuoka 812 \\ (Received October 5, 1981)
}

\begin{abstract}
In this study demineralization of low ash, partially demineralized copper-aluminum-pectin complex (CAPC) by using ion exchange resin (IER) is reported. Copper content of the pectin prepared by alcohol method was about $1 \mathrm{mg} \%$ dry basis (d. b.), hence, this value was taken as acceptable limit for the pectins produced by copper method. Performance of the IER was poor when demineralization was tried by mixing Diaion SK 1B, IER and CAPC solution. Three to four \% CAPC solutions can be demineralized by passing through Diaion PK 212, strong acid, H+ form, porous type resin in a column at $60^{\circ} \mathrm{C}$ at space velocity (S. V.) 5-7 liters/hr. Three of CAPC solution was more suitable for deminralization than higher concentration solutions. Two step demineralization by first passing through IER column at high $\mathrm{S}$. V. and then washing out leaked metal ions with acidified alcohols $(5 \%, 8 \%$ and $10 \% \mathrm{H}_{2} \mathrm{SO}_{4} \mathrm{v} / \mathrm{v}$ ) holds promise for demineralization and pectin modification simultaneously.
\end{abstract}

\section{INTRODUCTION}

Satsuma mandarin (Citrus unshiu Marc.) occupies the first place among citrus varieties grown in Japan. Handling of the peel left after expression of oranges is becoming more and more serious problem for the juice producers due to huge amount of energy consumed to dry the residue and selling it at low price as animal feed. This financial burden can be transformed into profit, if a method of proper utilization of peel is discovered.

Commercially peel is being used for production of pectin, peel oil and work is also in progress to recover vitamin $\mathrm{P}$, natural color, carbohydrate, cellulose etc. In other words citrus juice industry is moving towards the complete utilization of the citrus fruit, leaving behind no residue.

Satsuma mandarin peel contains about $50 \%$ less pectin as compared to other citrus varieties used for pectin manufacture as reported by Kausar and Nomura (1980).

This study was an attempt to explore the possibility of producing economically competiable pectin from low pectin citrus peel. To cut down the pectin manufacture cost idea was focused on

1) Process should be based on the utilization of wet leached peel.

2) Simple to produce and quickly purifiable low ash dry metal-pectin com- 
plex of good soluhility should be produced at juice plants and then pooled together in a central pectin manufacturing plant for further purification.

In this part of study demineralization of dry Cu-Al-pectin complex (CAPC) by using ion exchange resin (IER) is described.

\section{MATERIALS AND METHODS}

Dry CAPC was prepared according to the procedure described by Kausar and Nomura (1981), out of the peel collected from Fukuoka-ken Engeiren Amagi Mikan Juice Factory during 1979-80 citrus season.

Solublizing the CAPC: Powdered CAPC was wetted with alcohol and slowly dispersed in the measured quantity of water under constant stirring to make $3 \%, 4 \%$ and $5 \%$ solutions. Mixing was continued till the complex was completely dissolved. Temperature of the CAPC solutions in all the experiments was raised accordingly after completely solublizing the complex at room temperature.

Measurement of the viscosity: Viscosity of 3-5\% CAPC solutions was measured by Brookfield viscometer (Keiko seizoh sho, Tokyo).

Relative consisteney: Relative consistency of $0.5 \%$ pectin solutions was measured by Ostwald pipette. Discharge time for distilled water at $30^{\circ} \mathrm{C}\left(t_{0}\right)=$ 68 sec. Consistency was calculated according to the formula R.C. $=t_{s} / t_{0}$, where $t_{s}$ represents discharge time for $0.5 \%$ pectin solution at $30^{\circ} \mathrm{C}$.

Demineralization of dry CAPC: Demineralization was carried out by following three methods:

a) CAPC solution was mixed with $1: 1$ (w/w dry CAPC: Diaion SK $1 \mathrm{~B}$, dry, $\mathrm{H}+$-form gel type) IER for a known time at room temperature, $45^{\circ} \mathrm{C}$ and $60^{\circ} \mathrm{C}$ in a batch process, samples were taken at time intervals and ion exchange was calculated after diluting $5 \mathrm{~g}$ IER free sample to $100 \mathrm{ml}$ with distilled water and then titrated with $0.05 \mathrm{~N} \mathrm{HaOH}$ using methyl red and methyl blue as indicator. Blank was run with every series of experiments, using sample before mixing with IER. IER was separated from CAPC solution by passing through a nylon screen, CAPC solution was then passed through Diaion PK 212, H+-form, porous type IER in column at S. V. 10 15liters/hr. Effluent was precipitated in alcohol, drained and pressed, neutralized and dried.

b) $3 \%$ CAPC solution was passed through Diaion PK 212, H+-form, porous

1- $8 \mathrm{~L}$ of $396 \mathrm{CAPC}$ soln passed through Diaion PK 212 porous type, H+-form IER in column (bed hight $8.5 \mathrm{~cm}$, vol. $500 \mathrm{ml}$ ) at $60^{\circ} \mathrm{C}, \mathrm{S}$. V. $20-25 \mathrm{~L} / \mathrm{hr}$.

2 - Precipitated in $70 \%$ alcohol, drained and pressed. $\left(\mathrm{Cu}^{2+}\right.$ content $=1.75$ $\mathrm{mg} \%$ dry basis ; Coefficient of variation-17.38 \%; $\mathrm{n}: 4)$

3- Ppt shreded and washed with $70 \%$ alcohol containing $5 \%, 8 \%$ and 10 \% $\mathrm{H}_{2} \mathrm{SO}_{4}(\mathrm{v} / \mathrm{v})$ for 1-3 hrs.

4- Drained and pressed, again washed with $75 \%$ alcohol to remove excess acid.

5- Drained and pressed, neutralized in $80 \%$ alcohol, drained, dried and ground.

Fig. 1. Two step demineralization of CAPC solution. 
type IER in column at $60^{\circ} \mathrm{C}$ at known S. V. Effluent was precipitated in alcohol, drained and pressed, neutralized and dried.

c) $3 \%$ CAPC solution was also demineralized according to the scheme described in Fig. 1. Samples were taken at time intervals for measuring $\mathrm{Cu}^{2+}$ and methoxyl (MeO) contents. Precipitates were separated and second washed with $75 \%$ alcohol to remove excess acid, again separated and dispersed in $80 \%$ alcohol. Precipitates were drained and pressed, neutralized, separated and dried.

\section{Analyses}

Copper estimation: Wet ashing of pectin samples was done by taking one g sample in a $100 \mathrm{ml}$ pyrex flask and $20 \mathrm{ml}$ of concentrated $\mathrm{HNO}_{3}$ (extra pure, analytical grade) and $3 \mathrm{ml}$ of $70 \% \mathrm{HClO}_{4}$ were added. Initial decomposition was allowed at room temperature after covering the mouth of flask with $1.5 \mathrm{~cm} \phi$ glass funnel. After one hour three drops of $n$-octyl alcohol were added and flask was transferred on a hot plate and heated to about $85^{\circ} \mathrm{C}$ for two hours, then temperature of the hot plate was raised to $150^{\circ} \mathrm{C}$ and heating was continued till clear solution appeared $(9 \sim 10 \mathrm{hr})$. At this stage funnel was removed from the flask and the temperature was raised to $200^{\circ} \mathrm{C}$. Heating was continued to dryness (no fumes of $\mathrm{HClO}_{4}$ remained in the flask). Flask was removed from the hot plate, cooled and $5 \mathrm{ml}$ of concentrated $\mathrm{HCl}$ and $2 \mathrm{ml}$ of distilled water were added. Mouth of the flask was covered with funnel and refluxed on the hot plate for 30 minutes and then heated to dryness. Flask was cooled and one $\mathrm{ml}$ of concentrated $\mathrm{HCl}$ and $5 \mathrm{ml}$ of distilled water were added and warmed, transferred into $10 \mathrm{ml}$ volumetric flask and filled up with distilled water. Copper contents were measured by using Beckman Atomic Absorption Spectrophotometer, Model NF 1B, operated under following conditions :

$\begin{array}{llll}\text { Wave length } & : & 3247 \AA \\ \text { Lamp current } & : & 12 \mathrm{~mA} \\ \text { Spectral band width } & : & 0.2 \mathrm{~nm} & \\ \text { Flame- } \mathrm{C}_{2} \mathrm{H}_{2}-\text { air fl a m e } & : & 1.3 \mathrm{liter} / \mathrm{min}, 10 \text { liter/min }\end{array}$

A blank was digested with every set of samples. Results were calculated by comparing with $1-5 \mathrm{ppm} \mathrm{Cu}^{2+}$ standard curve.

Jelly rupture point: Jelly rupture point was measured by using Instron Universal testing machine, operated at chart speed $1,000 \mathrm{~mm} / \mathrm{min}$, plunger speed $200 \mathrm{~mm} / \mathrm{min}$, plunger size $12.5 \mathrm{~mm} \phi$.

All other analyses were made according to AOAC (1960) and methods used at West Regional Research Laboratory, California, for extraction and analysis of pectic materials (Owens et al., 1952).

\section{RESULTS AND DISCUSSION}

Three main factors governing demineralization of the CAPC by using IER were considered to be viscosity of the influent, space velocity (S. V.) of the influent and the bed height of IER in column. 


\section{lization \\ Effect of concentration and temperature of CAPC solution on the deminera-}

As the viscosity of CAPC solution depends upon concentration and temperature, their effect on the apparent viscosity measured by Brookfield viscometer is shown in Fig. 2. Results showed that viscosity of the CAPC solution decreased about three times in each case when concentration of the solution was decreased from $5 \%$ to $4 \%$, and from $4 \%$ to $3 \%$. At the same time it was further noted that when the temperature of CAPC solution was raised from $24^{\circ} \mathrm{C}$ to $60^{\circ} \mathrm{C}$, viscosity again decreased about three folds in all the cases $(5 \%, 4 \%$ and $3 \%)$. Average apparent viscosity of the $3 \%$ CAPC solution was around $260 \mathrm{C}$. P. at $60^{\circ} \mathrm{C}$. When the concentration of pectin solution was lower than $3 \%$ it consumed a lot of more alcohol to precipitate the pectin, hence, $3 \%$ CAPC solution at $60^{\circ} \mathrm{C}$ was preferred for demineralization. It was further noted that if excessive quantity of alcohol was used during solublization of the CAPC, resulting solution will have many folds high viscosity, which hindered demineralization as compared to the CAPC solution made under well controlled condition, CAPC solublized under slight vacuum to prevent aeration of the sample during mixing did not show any marked difference in apparent viscosity when compared with the solution made in an open vessel. Solublization in an open vessel incorporates a lot of air in the sample which will impair IER efficiency, therefore, solublization should be carried out under slight vacuum condition.

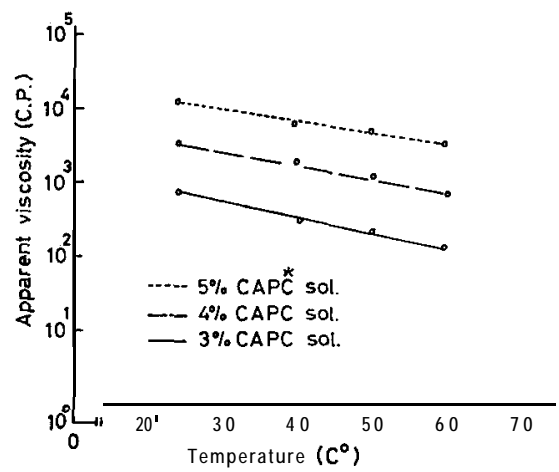

Fig. 2. Mean apparent viscosity of CAPC solutions at different temperature and concentrations. *: Copper-aluminum-pection complex. $\mathrm{n}: 3$.

\section{Effect of mixing IER and CAPC solution on the demineralization}

It was thought that mixing IER and CAPC after suspending in water will help solublization of the complex by picking up of metal ions. Observations lead to the conclusion that without prior solublization of CAPC, it sticks to the IER beads and clog the resin, moreover, clots appeared which hinder both solublization and demineralization. Percent ion exchange on mixing IER and CAPC solutions at different temperatures is shown in Fig. 3. Results revealed that percent ion exchange was less than $25 \%$ and that exchange was much 
quicker at higher temperatures. Results showed that when IER and CAPC solution was mixed at $60^{\circ} \mathrm{C}$, IER reached equilibrium within 40 minutes, whereas, it took about 2 hours at $20^{\circ} \mathrm{C}$. Diaion, SK $1 \mathrm{~B}, \mathrm{H}+$-form, strong acid gel type IER was used for demineralization by mixing because it was stronger to withstand breakage during mixing as compared to the porous type IER. These results lead to the conclusion that volume of IER ( $1: 1$ dry CAPC and IER w/w d. b.) required was much larger, moreover, preferential demineralization for tri and di-valent ions might not be taking place due to colloidal and viscus nature of the solution. Too large volume of IER and poor demineralization during mixing makes this step uneconomical, hence, mixing step was dropped.

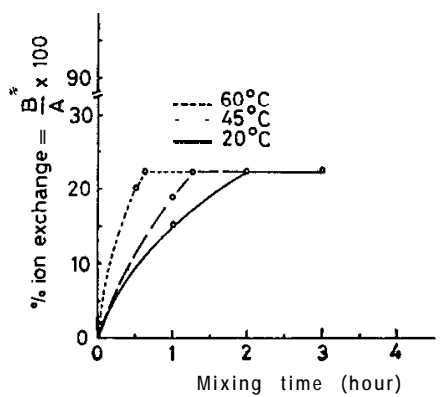

Fig. 3. Average ion exchange in 3\% \&-Al-pectin complex solution by mixing with IER (strong acid, cation, gel type**). *B: Ion exchanged in $\mathrm{Cu}$-Al-pectin complex soln. *A: Total ion exchange capacity in $\mathrm{CuCl}_{2}$ soln, $(\mathrm{meq} / \mathrm{ml})(\min )=1.5$; **: Diaion SK $1 \mathrm{~B} ; \mathrm{n}: 4$. Note : Same lot of $\mathrm{Cu}$-Al-pectin complex was used in all the experiments.

\section{Demineralization by passing through IER in column}

Three factors namely concentration of the CAPC solution, S.V. of the influent and IER bed height in column were investigated. Effect of CAPC solution concentration on the demineralization by passing through Diaion PK 212, $\mathrm{H}^{+}$-form, strong acid porous type IER in column is shown in Table 2. Results revealed that $5 \%$ CAPC solution could not be demineralized with in the acceptable range $\left(\mathrm{Cu}^{2+}\right.$ content $1 \mathrm{mg} \% \mathrm{~d}$. b. as in case of pectin prepared by alcohol method by using the same pectin pomace) due to high leakage of

Table 1. Variation between dry $\mathrm{CAPC}^{11}$ batches prepared from the same lot of pectin pomace (dry basis).

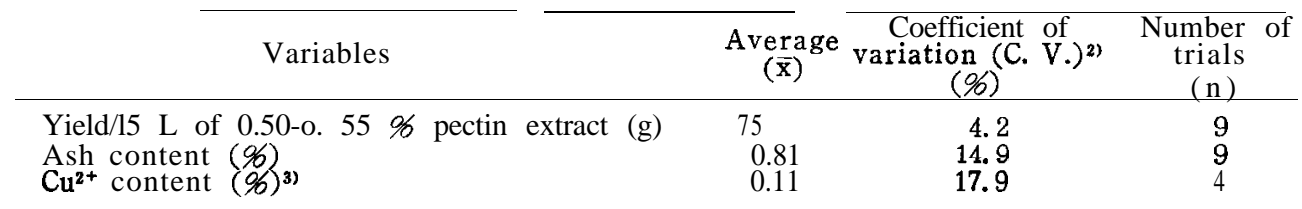

1: Copper-aluminum-pectin complex.

2: $(100 \times(\mathrm{S} / \mathrm{X}))$.

3: Copper contents were measured by colorimetric method described by E. B. Sandell (1959). 
Table 2. Effect of CAPC1) solution concentration on the demineralization by passing through IER $^{2}$ column.

\begin{tabular}{cccccccc}
\hline & \multicolumn{2}{c}{ Influent type } & \multicolumn{2}{c}{ Column } & condition & \multicolumn{2}{c}{ Product type } \\
\hline $\begin{array}{c}\text { Total } \\
\text { volume } \\
(\mathrm{L})\end{array}$ & $\begin{array}{c}\text { Conc. of } \\
\text { solution } \\
(\%)\end{array}$ & Temp. & $\begin{array}{c}\text { Space } \\
\text { velocity } \\
(\mathrm{L} / \mathrm{hr} .)\end{array}$ & $\begin{array}{c}\text { Resin wet } \\
\text { volume } \\
(\mathrm{ml})\end{array}$ & $\begin{array}{c}\text { Resin bed } \\
\text { height } \\
(\mathrm{cm})\end{array}$ & $\begin{array}{c}\text { Copper } \\
\text { content } \\
(\mathrm{mg} \%)\end{array}$ & $\begin{array}{c}\text { c. V.3) } \\
(\mathrm{n}=4) \\
(\%)\end{array}$ \\
\hline 4.8 & 5 & 60 & $5-7$ & 500 & 8.5 & 1.85 & 6.98 \\
6.0 & 4 & 60 & $5-7$ & 500 & 8.5 & 0.88 & 12.27 \\
8.0 & 3 & 60 & $5-7$ & 500 & $8: 5$ & 0.70 & 12.61 \\
\hline
\end{tabular}

1: Copper-aluminum-pectin complex.

2: Diaion PK 212. strong acid, cation, porous type ion exchange resin.

3: Coefficient of variation ; $(100 \times(\mathrm{S} / \overline{\mathbf{x}}))$.

metal ions, even when passed through the column at S. V. 5-7 liters/hr at $60^{\circ} \mathrm{C}$. When $4 \%$ and $3 \%$ CAPC solutions were passed through the IER in a column under similar conditions as in case of $5 \%$ solution, contained less than Img \% copper d. b. Results revealed that 3-4 \% CAPC solutions were suitable for demineralization when passed through the IER in column at $60^{\circ} \mathrm{C}$ and at S. V. 5-7 liters/ hr.

\section{Effect of influent space velocity on the demineralization}

Effect of S.V. on the demineralization of CAPC solution is shown in Table 3. Results revealed that when influent S.V. was increased to 14-16 and 18 20 liters/hr in case of $4 \%$ CAPC solution, leakage of $\mathrm{Cu}^{2+}$ ions increased to 1.68 and $2.03 \mathrm{mg} \% \mathrm{~d}$. b., respectively. Quantity of copper in both the cases was higher than the copper contents of the natural pectin. These effluents when passed second time through the same used IER at S.V. 8 10 liters/ hr the copper contents of the products were within the acceptable range (less than $1 \mathrm{mg} \% \mathrm{~d}$. b.). These results indicated that the used IER still had the demineralization capacity if the contact time between IER and metal ions was increased by slowing down S.V. of the influent. Leakage of metal ions at

Table 3. Effect of CAPC1) solution space velocity on the demineralization by passing through IER $^{2)}$ column.

\begin{tabular}{|c|c|c|c|c|c|c|c|}
\hline \multicolumn{4}{|c|}{ Influent type } & \multicolumn{2}{|c|}{ Column condition } & \multicolumn{2}{|c|}{ Product type } \\
\hline $\begin{array}{c}\text { Total } \\
\text { volume } \\
\text { (L) }\end{array}$ & $\begin{array}{l}\text { Conc. of } \\
\text { solution } \\
(\%)\end{array}$ & $\begin{array}{l}\text { Temp. } \\
\text { (“C) }\end{array}$ & $\begin{array}{l}\text { Space } \\
\text { velocity } \\
(\mathrm{L} / \mathrm{hr} .)\end{array}$ & $\begin{array}{l}\text { Resin } \\
\text { volume } \\
\quad(\mathrm{ml})\end{array}$ & $\begin{array}{c}\text { Resin bed } \\
\text { height } \\
(\mathrm{cm})\end{array}$ & $\begin{array}{l}\text { Copper } \\
\text { content } \\
(\mathrm{mg} \quad \%)\end{array}$ & $\begin{array}{c}\text { c. V.3) } \\
\mathrm{n}=4) \\
(\%)\end{array}$ \\
\hline 6.0 & 4 & $\begin{array}{l}60 \\
60\end{array}$ & $5-7$ & 500 & 8.5 & 0.88 & 12.27 \\
\hline $\begin{array}{l}6.0 \text { (a) } \\
6.0 \text { (b) }\end{array}$ & $4^{4}$ & $60^{\circ}$ & $\begin{array}{l}18-20 \\
14-16\end{array}$ & $\begin{array}{l}500 \\
500\end{array}$ & 8.5 & $\begin{array}{l}2.03 \\
1.68\end{array}$ & $\begin{array}{l}16.36 \\
16.89\end{array}$ \\
\hline and & pass & 60 & $8-10$ & 500 & 8.5 & 0.91 & 8.74 \\
\hline
\end{tabular}

1: Copper-aluminum-pectin complex.

2: Diaion PK 212. strong acid, cation, porous type ion exchange resin.

3: Coefficient of variation ; $(\mathbf{1 0 0} \times(\mathbf{S} / \mathbf{X}))$. 
S.V. s $14-16$ and $18 \sim 20$ liters/hr in case of $4 \%$ CAPC solutions might be due to short contact time between IER and metal ions, high viscosity or higher concentration of ions per unit volume of the influent.

\section{Effect of IER bed height on the demineralization}

Effect of IER bed height on the demineralization of $3 \%$ CAPC solution is shown in Table 4. Results revealed that when IER bed height was decreased from $8.5 \mathrm{~cm}$ to $3.3 \mathrm{~cm}$ but influent was allowed same contact time (S.V. 5-7 liters/hr) with IER, demineralization results were the same. Moreover, when S.V. was increased to $8 \sim 10$ litersjhr even then copper content of the product were within the safe limit in case of $3 \%$ CAPC solution. Comparison of Tables 3 and 4 reflects that $3 \%$ CAPC solution showed better demineralization results than $4 \%$ solution, which might be due to low viscosity or low concentration of ions per unit volume in case of $3 \%$ CAPC solution.

Table 4. Effect of IER $^{1)}$ column bed height on the demineralization of $3 \%$ $\mathrm{CAPC}^{2)}$ solution.

\begin{tabular}{|c|c|c|c|c|c|c|c|}
\hline \multirow{2}{*}{\multicolumn{4}{|c|}{ Influent type }} & \multirow{2}{*}{\multicolumn{2}{|c|}{ Column condition }} & \multirow{2}{*}{\multicolumn{2}{|c|}{$\overline{\text { Product type }}$}} \\
\hline & & & & & & & \\
\hline $\begin{array}{l}\text { Total } \\
\text { volume } \\
(\mathbf{L})\end{array}$ & $\begin{array}{l}\text { Conc: of } \\
\text { solution } \\
(\%)\end{array}$ & $\begin{array}{l}\text { Temp. } \\
\left({ }^{\circ} \mathrm{C}\right)\end{array}$ & $\begin{array}{c}\text { Space } \\
\text { velocity } \\
\text { (L/hr.) }\end{array}$ & $\begin{array}{c}\text { Resin wet } \\
\text { volume } \\
(\mathrm{ml})\end{array}$ & $\begin{array}{c}\text { Resin bed } \\
\text { height } \\
(\mathrm{cm}) \\
\end{array}$ & $\begin{array}{l}\text { Copper } \\
\text { content } \\
(m g \%)\end{array}$ & $\begin{array}{c}\text { c. V.3) } \\
(\mathrm{n}=4) \\
(\%)\end{array}$ \\
\hline 8 & 3 & 60 & $8-10$ & 500 & 8.5 & 0.82 & 12. 5 \\
\hline 8 & 3 & 60 & $5-7$ & 500 & 8.5 & 0.70 & 12.6 \\
\hline 8 & 3 & 60 & $5-7$ & 500 & 8.5 & 0.73 & 15.1 \\
\hline
\end{tabular}

1: Diaion PK 212. strong acid, cation, porous type ion exchange resin.

2 : Copper-aluminum-pectin complex.

3: Coefficient of variation; $(100 \times(\mathrm{S} / \mathrm{X}))$.

\section{Two step demineralization by IER and acidified alcohol}

Flow diagram of two step demineralization of $3 \%$ CAPC solution by first

Table 5. Copper and methoxyl contents of the two step demineralized products.

\begin{tabular}{|c|c|c|c|c|}
\hline \multirow[b]{2}{*}{$\begin{array}{c}\mathrm{H}_{2} \mathrm{SO}_{4} \text { in } 70 \% \\
\text { alcohol } \\
(\mathrm{v} / \mathrm{v})\end{array}$} & \multirow[b]{2}{*}{$\begin{array}{r}\text { Washing } \\
(h \mathbf{r})\end{array}$} & \multicolumn{2}{|c|}{ Copper content } & \multirow[b]{2}{*}{$\begin{array}{c}\text { Methoxyl } \\
\text { content } \\
(\%)\end{array}$} \\
\hline & & $\begin{array}{c}\mathrm{mg} \% \\
(\mathrm{x})\end{array}$ & $\begin{array}{l}\text { c. V.1) } \\
(n=4) \\
(\mathscr{G})\end{array}$ & \\
\hline $5 \%$ & $\begin{array}{l}1 \\
2 \\
3\end{array}$ & $\begin{array}{l}0.56 \\
\text { na }{ }^{2)} \\
\mathrm{na}\end{array}$ & 15.83 & $\begin{array}{l}8.37 \\
8.37 \\
8.37\end{array}$ \\
\hline $8 \%$ & $\begin{array}{l}1 \\
2 \\
3\end{array}$ & $\begin{array}{l}0.25 \\
\mathrm{na} \\
\mathrm{na}\end{array}$ & 12.65 & $\begin{array}{c}7.95 \\
7.71 \\
\mathrm{na}\end{array}$ \\
\hline $10 \%$ & $\begin{array}{l}2 \\
3\end{array}$ & $\begin{array}{l}0.18 \\
\text { na } \\
\text { n a }\end{array}$ & $\begin{array}{r}19.84 \\
-\end{array}$ & $\begin{array}{r}7.02 \\
7.02 \\
-\end{array}$ \\
\hline
\end{tabular}

1: Coefficient of variation; $(100 \times(\mathrm{S} / \mathrm{x}))$.

2: not analysed. 
passing through IER in a column at S.V. 20-25 liters/hr and then washing out the leaked ions with acidified alcohol after precipitating the pectin in the effluent with alcohol are shown in Fig. 1. Results showed that the leakage of metal ions at S.V. $20-25$ liters $/ \mathrm{hr}$ was $1.75 \mathrm{mg} \%$ d.b. as compared to $2.03 \mathrm{mg} \% \mathrm{~d}$. b. in case of $4 \%$ CAPC solution, when passed through the column at S.V. 18-20 liters/hr (Table 3). Effluent after precipitating in alcohol, when washed with $70 \%$ alcohol containing $5 \% \mathrm{v} / \mathrm{v} \mathrm{H}_{2} \mathrm{SO}_{4}$ (Table 5) reduced the copper contents to $0.56 \mathrm{mg} \% \mathrm{~d} . \mathrm{b}$. , at the same time methoxyl contents decreased from $8.7 \%$ to $8.3 \%$ after one hour. When acid contents were increased to $8 \%$ and $10 \%$, copper contents decreased to 0.25 and $0.18 \mathrm{mg} \%$ d.b. and methoxyl contents decreased to $7.9 \%$ and $7.0 \%$, respectively. These results showed that in case of two step demineralization $4 \%$ CAPC solution can also be demineralized successfully. Moreover, with slight temperature increase during washing with acidified alcohol, demineralization and simultaneous modification of pectin seems possible.

\section{Qualitative analyses}

Analyses of differently prepared pectins are reported in Table 6. Results revealed that consistency of $0.5 \%$ pectin solution decreased from 6.50 to 3.29 when pectins prepared by using IER only and two step demineralization by using $10 \% \mathrm{H}_{2} \mathrm{SO}_{4}$ were compared, jelly rupture point also decreased from $58 \mathrm{~g} /$ $\mathrm{cm}^{2}$ to $39 \mathrm{~g} / \mathrm{cm}^{2}$, respectively. This decreased in quality might be attributed to the degradation of pectin molecule by acid treatment. Low consistency and jelly rupture strength in case of pectin prepared by alcohol method as compared to the pectin prepared by copper method using IER only (both pectins prepared from the same pectin pomace) might be due to low purity (AGA) and/or interference by impurities.

Table 6. Qualitative analysis of pectins prepared from $\mathrm{CAPC}^{12}$ by different treatments (dry basis).

\begin{tabular}{|c|c|c|c|c|c|c|}
\hline Preparation method & $\begin{array}{l}\text { Ash } \\
(\%)(\end{array}$ & $\mathrm{Cu}^{2+}$ & $\begin{array}{l}\text { AGA2) } \\
\%) \mathrm{pe}\end{array}$ & $\begin{array}{l}\text { Consistency } \\
\text { of } 0.5 \% \\
\text { ctin sol. }\end{array}$ & $\begin{array}{l}\text { Methoxyl } \\
\text { content } \\
(\%)\end{array}$ & $\begin{array}{c}\text { Jelly } \\
\text { rupture } \\
\text { point } \\
\left(\mathrm{g} / \mathrm{cm}^{2}\right)\end{array}$ \\
\hline $\begin{array}{l}\text { Extra pure pectinin } \\
\text { Alcohol process } \\
\text { (5) }\end{array}$ & $\begin{array}{l}3.90 \\
1.66\end{array}$ & $\begin{array}{l}1.00 \\
0.93\end{array}$ & $\begin{array}{l}67.5 \\
75.0\end{array}$ & $\begin{array}{l}4.61 \\
4.75\end{array}$ & 6.6 & $\begin{array}{l}45 \\
46\end{array}$ \\
\hline 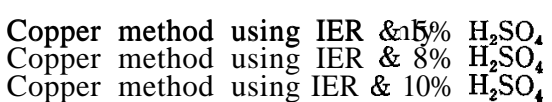 & $\begin{array}{l}0:(064 \\
0.04 \\
0.03\end{array}$ & $\begin{array}{l}0: 50 \\
0.25 \\
0.18\end{array}$ & $\begin{array}{l}\text { 88:0 } \\
87.0 \\
87.0\end{array}$ & $\begin{array}{l}\text { 4.5.54 } \\
3.73 \\
3.29\end{array}$ & $\begin{array}{l}8.7 \\
7.9 \\
7.0\end{array}$ & $\begin{array}{l}47 \\
43 \\
39\end{array}$ \\
\hline
\end{tabular}

1: Copper-aluminum-pectin complex.

2: Anhydrogalacturonic acid.

3: Ratio of the discharge time of $0.5 \%$ pectin solution divided by the discharge time of water at $30^{\circ} \mathrm{C}$.

4: Obtained from Ishizu Pharmaceutical Co., LTD., Osaka, Japan.

5: Prepared from the same pectin pomace as in case of copper method.

It should be kept in mind that possibilities, trends and conclusions made in this paper need further pilot scale experimentation to the full capacity of 
IER to make perfect decision, which are out of scope of laboratory scale experiments.

\section{ACKNOWLEDGEMENTS}

Authors are extremely thankful to Miss Kazue Tatsuguchi for measuring $\mathrm{Cu}^{2+}$ contents of the samples. Peel samples were collected from Fukuoka-ken Engeiren Amagi Mikan Juice Factory.

\section{REFERENCES}

AOAC 1960 Methods of Analysis. 9th ed. Assoc. Official Anal. Chem., Washington D.C.

Kausar, P. and D. Nomura 1980 A new approach to pectin manufacture by copper method. Part 1. Preparation of pectin pomace. pectin extraction and concentration by copper salt. J. Fac. Agr., Kyushu Univ., 25 (2 - 3): 61-71

Kausar, P. and D. Nomura 1981 A new approach to pectin manufacture by copper method. Part 2. Preparation of dry metal-pectin complex. J.Fac. Agr., Kyushu Univ., 26 (1) : 1-7

Owens, H. S., R. M. McCready, A. D. Shepherd, T. H. Schultz, E. L. Pippen, H. A. Swenson, J. C. Miers. R. F. Erlandsen and W. D. Maclay 1952 Methods for extraction and analysis of pectic materials used at Western Regional Research Laboratory. Pub. Bureau Agr. Indust. Chem.. Agr. Res. Admin., USDA, 340: I-24

Sandell, E. B. 1959 Colorimetric Determination of Traces of Metals. Vol. 3, 3rd ed. revised by E. B. Sandell, Interscience Publishers, Inc., New York, pp. 451-453 